\title{
Dietary protein restriction during lactation in primiparous sows with different live weights at farrowing: I. Consequences on sow metabolic status and litter growth
}

\author{
Hélène QUESNEL ${ }^{\mathrm{a} *}$, César A. MEJIA-GUADARRAMA ${ }^{\mathrm{b}}$, \\ Jean-Yves DOURMAD ${ }^{\mathrm{a}}$, Chantal FARMER ${ }^{\mathrm{c}}$, Armelle PRUNIER ${ }^{\mathrm{a}}$ \\ ${ }^{a}$ Unité Mixte de Recherche sur le Veau et le Porc, INRA, 35590 Saint-Gilles, France \\ ${ }^{\mathrm{b}}$ Centro Nacional de Investigación en Fisiología Animal, INIFAP, Querétaro, México \\ c Agriculture and Agri-Food Canada, Dairy and Swine R \& D Centre, Lennoxville, QC, Canada J1M1Z3
}

(Received 18 June 2004; accepted 4 October 2004)

\begin{abstract}
The hypothesis that the restriction of dietary protein during lactation has different impacts on sow metabolic status and milk production according to body weight was evaluated. From 5-months of age until farrowing, the gilts were fed to achieve body weights of 180 or $240 \mathrm{~kg}$ at farrowing. At this time, 38 sows were assigned to one of three groups: " $180 \mathrm{~kg}$ " sows not restricted in dietary protein during lactation (180CP); "180 kg" restricted in protein (180LP), or " $240 \mathrm{~kg}$ " sows restricted in protein (240LP). Catheters were fitted in the jugular vein of 24 sows and serial blood samples were collected $1 \mathrm{~d}$ before and $1 \mathrm{~d}$ after weaning. Amongst the protein-restricted animals, heavy sows (240LP) had a smaller appetite than light sows in early lactation, resulting in lower energy and protein intakes in the 240LP than in the 180LP sows. Body protein losses were 8,11 and $13.5 \%$ of calculated body protein mass at farrowing in the 180CP, 180LP and 240LP sows, respectively. At the end of lactation, IGF-I concentrations were lower in the 180LP than in the sows from the other groups, probably because of the uncoupling between GH and IGF-I secretions. Low IGF-I concentrations likely promote lean tissue mobilization. Glucose and insulin profiles suggested an insulin resistance state in the 240LP sows compared with the 180LP sows, which may explain, at least in part, the lower feed intake and body reserve mobilization in these sows. Plasma pre- and post-prandial concentrations of amino acids in late lactation differed among the three treatment groups. Throughout lactation, litters from the 180LP and 240LP sows had a slower growth rate than litters from sows which were not restricted, suggesting that endogenous protein mobilization throughout lactation does not completely compensate for a low protein intake.
\end{abstract}

sow / live weight / lactation / protein intake / IGF-I / insulin

\section{INTRODUCTION}

Primiparous sows generally mobilize body reserves to meet the high energy and nutrient requirements for milk production [1,2].
Body reserve mobilization depends on the amplitude and the origin of the nutritional deficit. Energy restriction induces mobilization of both fat and protein reserves but has a limited influence on milk production,

* Corresponding author: Helene.Quesnel@ rennes.inra.fr 
except in cases of extreme energy deficit and low or depleted body reserves. Low protein intake during lactation amplifies muscle protein mobilization [3-5]. It may compromise milk production in primiparous sows $[4,6,7]$, but this effect of dietary protein restriction during lactation on litter growth is not always observed [8]. Such discrepancies between experiments could be explained by restriction intensity or by differences in sow body weight. Indeed, when nutrient intake is low during lactation, milk production is likely to depend on the amount of body reserves at farrowing [9]. The present study was aimed at testing the hypothesis that large body reserves at farrowing may prevent the detrimental influence of a severe restriction in dietary protein during lactation. Consequences of a restriction in sow dietary protein (lysine) on litter growth, sow body reserve mobilization and metabolic status were investigated. Since subsequent reproductive performance was shown to be influenced by sow metabolic status in late lactation and after weaning [10, 11], physiological measurements were focused around weaning.

\section{MATERIALS AND METHODS}

\subsection{Animals and general management}

The experiment was conducted with four replicates of Pietrain $\times$ (Landrace $\times$ Large White) crossbred gilts. At the age of $151 \pm$ $4 \mathrm{~d}, 56$ prepubertal gilts were randomly assigned to a group of " $180 \mathrm{~kg}$ " or " $240 \mathrm{~kg}$ " gilts, according to the objectives of live weight at farrowing. After two or three estruses, the estrous cycles were synchronized by a progestagen treatment for $18 \mathrm{~d}$ (Regumate ${ }^{\circledR}, 20 \mathrm{mg} \cdot \mathrm{d}^{-1}$, Janssen-Cilag, Issyles-Moulineaux, France). After treatment withdrawal, estrus was detected twice daily by contact with a mature boar. Fifty-two gilts were inseminated with fresh diluted semen from Pietrain boars at $265 \pm 1 \mathrm{~d}$ of age and $136 \pm 11 \mathrm{~kg}$ (group " $180 \mathrm{~kg}$ "; $n=31$ ) or $189 \pm 14 \mathrm{~kg}$ live weight (group " $240 \mathrm{~kg}$ ”; $n=21)$. On d $104 \pm 1$ of gestation, the gilts were moved from gestation to the farrowing units and were kept in individual farrowing crates $(2 \times 2.5 \mathrm{~m})$ in a building maintained between 20 and $25{ }^{\circ} \mathrm{C}$. When necessary, parturition was induced by an i.m. injection of $2 \mathrm{~mL}$ of cloprostenol (Planate, Mallinckrodt veterinary, Meaux, France) on d 114 of gestation. Farrowing occurred on d 114 or 115 of gestation. Within $48 \mathrm{~h}$ after birth, the litters were standardized to 11 piglets and 10 piglets $3 \mathrm{~d}$ later. The piglets that died during the first week of lactation were weighed and replaced by piglets of similar weight and age. Throughout lactation, the piglets had no access to creep feed. They were weaned between 0830 and 0930 at $28 \pm 1 \mathrm{~d}$ of age. Water was freely available for the sows and piglets throughout the experimental period.

\subsection{Diets}

Until insemination, the gilts were fed a standard growing pig diet containing $13.4 \mathrm{MJ}$ of digestible energy (DE), $174 \mathrm{~g}$ of crude protein $(\mathrm{CP})$ and $8.5 \mathrm{~g}$ of lysine per $\mathrm{kg}$. The allowance was on average 1.9 and $3.4 \mathrm{~kg} \cdot \mathrm{d}^{-1}$ for " $180 \mathrm{~kg}$ " and " $240 \mathrm{~kg}$ " gilts, respectively, in order to meet 1.6 and $2.4 \times$ energy requirements for maintenance. This need was calculated according to the metabolic weight of the gilts [2]. During gestation, all females received a standard diet containing $12.1 \mathrm{MJ}$ $\mathrm{DE} \cdot \mathrm{kg}^{-1}, 13 \% \mathrm{CP}$ and $0.6 \%$ lysine. The daily feed allowance was adjusted every three weeks in order to meet $110 \%$ of the energy requirements for gestation [12]. On the day of farrowing, all females were provided $1 \mathrm{~kg}$ of the gestation diet. During lactation, the daily feed allowance was given in two equal meals provided at 0830 and 1430 . One day after farrowing, 38 sows were allocated to one of three groups: (1) "180 kg" sows not restricted in dietary protein during lactation (180CP); (2) "180 kg" sows restricted in protein (180LP); and (3) "240 kg" sows restricted in protein (240LP). The diets were formulated on the basis of lysine being the first-limiting amino acid (AA), with 
other AA meeting or exceeding the suggested "ideal" ratio for each AA relative to lysine for lactating sows [13] (Tab. I). The diets provided similar amounts of metabolizable energy $\left(13.0 \mathrm{MJ} \cdot \mathrm{kg}^{-1}\right)$. The lysine content amounted to $1.02,0.57$ and $0.52 \%$ in the 180CP, 180LP and 240LP diets respectively. Lysine/energy ratio was slightly lower for the 240LP than for the 180LP sows in order to compensate for their higher energy requirement for maintenance. On d 1 and 2 postpartum, all females received 2.5 and $3.5 \mathrm{~kg} \cdot \mathrm{d}^{-1}$ of the experimental diet, respectively. Thereafter, the amount of feed was restricted to $4.3 \mathrm{~kg} \cdot \mathrm{d}^{-1}$ for the $180 \mathrm{CP}$ and $180 \mathrm{LP}$ sows and $4.5 \mathrm{~kg} \cdot \mathrm{d}^{-1}$ for the $240 \mathrm{LP}$ sows of the experimental diets throughout lactation, in order to avoid differences in feed consumption and to obtain the same ratio of energy ingested to energy requirements $(\sim 70 \%)$ for all sows. Feed refusals were weighed daily before the morning meal and actual feed intake was then calculated.

From the day of weaning (day W) until the end of the experiment, all sows received a conventional gestation diet containing $12.1 \mathrm{MJ} \mathrm{DE} \cdot \mathrm{kg}^{-1}, 13 \% \mathrm{CP}$ and $0.6 \%$ lysine, in two equal meals given at around 0830 and 1430. After weaning, the sows remained in their farrowing crate for $2 \mathrm{~d}$ in order to facilitate serial blood sampling. Thereafter, they were moved and penned in individual gestation crates $(0.7 \times 2.5 \mathrm{~m})$ until the end of the experiment. They were monitored for estrus after weaning and artificially inseminated. The sows were slaughtered $30 \pm 1 \mathrm{~d}$ after insemination for examination of the genital tracts. This part is extensively described in a companion paper [14].

\subsection{Measurements and sampling}

The gilts were weighed every two weeks until the first insemination, then every three weeks during gestation. Backfat thickness was measured ultrasonically at $65 \mathrm{~mm}$ on each side of the dorsal midline at the level of the last rib (P2) at $150 \mathrm{~d}$ of age and at first insemination. During lactation, sow live weight and backfat thickness were recorded
$1 \mathrm{~d}$ after farrowing and at 7, 14, 21 and $28 \pm$ $1 \mathrm{~d}$ postpartum. The piglets were weighed at birth and at 7, 14, 21 and $28 \pm 1 \mathrm{~d}$ of age.

A subgroup of sows was randomly allocated to blood sampling (8/group). On d 22 \pm 1 of lactation, catheters were surgically inserted into the jugular vein of these sows under general anaesthesia [15]. The sows were deprived of feed $16 \mathrm{~h}$ before the surgery and were returned to their farrowing crate and re-fed $1 \mathrm{~h}$ after surgery. Serial blood samples were collected via a catheter every 15 min from 0815 to 1615 on the day before (day W-1) and on the day after (day $\mathrm{W}+1$ ) weaning. Feeding troughs were emptied (when necessary) at around 1600 on the day before serial blood sampling. Blood samples were collected in heparinized tubes and immediately centrifuged at $4{ }^{\circ} \mathrm{C}$ for harvesting of plasma. Plasma samples were stored at $-20{ }^{\circ} \mathrm{C}$ until assayed.

The animals were reared in compliance with national regulations for the humane care and use of animals in research (certificate of authorization to experiment on living animals No. 7675 delivered by the French Department of Agriculture).

\subsection{Metabolite and hormone assays}

Automated enzymatic methods using a Cobas Mira multichannel analyzer (Hoffman Laroche, Basel, Switzerland) were performed to determine plasma concentrations of glucose (bio-Mérieux kits ref 61272, Marcyl'Étoile, France), non-esterified fatty acids (NEFA, Wako Chemical NEFA C, Neuss Germany), urea (Urea unimate 5, ref.073685-6, Roche, Neuilly-sur-Seine, France) and $\alpha$-amino nitrogen [16] on days $\mathrm{W}-1$ and $\mathrm{W}+1$. Concentrations of glucose were measured at 0830 (before the morning meal) and every $15 \mathrm{~min}$ from 0930 to 1030 . Urea, NEFA and $\alpha$-amino nitrogen were determined at 0815 and 1215. Plasma AA concentrations were measured on day $\mathrm{W}-1$ according to the procedure described by Sève et al. [17]. Briefly, plasma was deproteinized with one volume of sulfosalicylic acid (6\%) combined 
Table I. Composition of the experimental diets during lactation.

\begin{tabular}{|c|c|c|c|}
\hline \multirow{3}{*}{ Ingredients, \% (as-fed basis) } & \multicolumn{3}{|c|}{ Treatment group ${ }^{1}$} \\
\hline & \multicolumn{3}{|c|}{ 180CP 180LP 240LP } \\
\hline & & & \\
\hline & 34.70 & 50.25 & 48.81 \\
\hline Corn starch & 0.00 & 7.97 & 9.75 \\
\hline Soybean meal & 25.40 & 1.53 & 1.22 \\
\hline Wheat & 30.00 & 30.00 & 30.00 \\
\hline Wheat bran & 3.00 & 3.00 & 3.00 \\
\hline Beat molasses & 3.00 & 3.00 & 3.00 \\
\hline Calcium carbonate & 0.55 & 0.48 & 0.46 \\
\hline Dicalcium phosphate & 1.95 & 2.30 & 2.31 \\
\hline Salt & 0.45 & 0.45 & 0.45 \\
\hline $\begin{array}{l}\text { Vitamin and mineral } \\
\text { premix }^{\mathrm{a}}\end{array}$ & 0.50 & 0.50 & 0.50 \\
\hline L-Lysine $\mathrm{HCl}, 78 \%$ & 0.22 & 0.35 & 0.34 \\
\hline DL-Methionine & 0.10 & 0.02 & 0.03 \\
\hline Tryptophan & 0.01 & 0.04 & 0.03 \\
\hline Threonine & 0.12 & 0.11 & 0.10 \\
\hline \multicolumn{4}{|c|}{ Nutrient composition, calculated } \\
\hline $\begin{array}{l}\text { Metabolizable energy, } \\
\mathrm{MJ} \cdot \mathrm{kg}^{-1}\end{array}$ & 12.9 & 13.1 & 13.1 \\
\hline Crude protein, $\%$ & 19.82 & 9.55 & 9.28 \\
\hline Calcium, $\%$ & 0.94 & 0.93 & 0.92 \\
\hline Phosphorus, \% & 0.76 & 0.71 & 0.70 \\
\hline \multicolumn{4}{|l|}{ Chemical analysis } \\
\hline $\begin{array}{l}\text { Metabolizable energy, } \\
\mathrm{MJ} \cdot \mathrm{kg}^{-1}\end{array}$ & 13.0 & 13.0 & 13.0 \\
\hline Crude protein, $\%$ & 18.3 & 9.7 & 9.0 \\
\hline Lysine, \% & 0.96 & 0.51 & 0.46 \\
\hline Methionine + cystine, $\%$ & 0.58 & 0.29 & 0.31 \\
\hline Threonine, \% & 0.72 & 0.40 & 0.34 \\
\hline Tryptophan content ${ }^{\mathrm{b}}, \%$ & 0.21 & 0.10 & 0.10 \\
\hline
\end{tabular}

a Supplied the following amounts $\mathrm{kg}^{-1}$ of diet: vitamin A, 10,000 IU; vitamin D3, 1500 IU; vitamin E $30 \mathrm{mg}$, vitamin $\mathrm{K} 3,2 \mathrm{mg}$; thiamine, $2 \mathrm{mg}$; riboflavin, $4 \mathrm{mg}$; nicotine acid, $15 \mathrm{mg}$; d-pantothenic acid, $10 \mathrm{mg}$; pyridoxine $3 \mathrm{mg}$; d-biotin, $0.2 \mathrm{mg}$; folic acid, $3 \mathrm{mg}$; vitamin B12, $0.02 \mathrm{mg}$; choline, $500 \mathrm{mg}$; Fe, 80 mg; Cu 10 mg, Mn, 40 mg; Zn, 100 mg; Co, $0.1 \mathrm{mg} ; \mathrm{I}, 0.6 \mathrm{mg}$ and Se, $0.15 \mathrm{mg}$.

b Calculated values based on INRA 1989 [13].

${ }^{1}$ Cf. Table II. with an internal standard (L- $\alpha$-amino- $\beta$ guanidinopropionic acid). Supernatants were adjusted to a pH of 2.2 with $100 \mu \mathrm{L}$ of citric acid $(0.5 \mathrm{~N}, \mathrm{pH} 5)$. Chromatographic separation of the AA was performed on a Biotronik LC 5001 analyzer (Biotronic Pusheim Bahnhof, Germany) using a $\mathrm{Li}^{+}$cation exchange column maintained between 33 and $66^{\circ} \mathrm{C}$ with post-column ninhydrin derivatization. A special run was used to analyze tryptophan. Plasma tryptophan was determined using a sample concentration 4 times higher than for the other AA at a column temperature of $75^{\circ} \mathrm{C}$ and quantified using the same chromatographic procedures.

Plasma concentrations of insulin, $\mathrm{GH}$, IGF-I, leptin and prolactin were measured on days $\mathrm{W}-1$ and $\mathrm{W}+1$. They were determined in duplicate using validated RIA [1821]. Leptin concentrations were determined with a multispecies double-antibody kit assay (Linco Research Inc, St. Louis, MO), which was previously validated for swine [22, 23]. The samples were run in two assays for insulin and IGF-I and in a single assay for $\mathrm{GH}$, leptin and prolactin. For insulin, the intra- and interassay $\mathrm{CV}$ were $7.1 \%$ and $11.5 \%$ at $40 \mu \mathrm{IU} \cdot \mathrm{mL}^{-1}$, respectively, and the average sensitivity of the assay, defined as $90 \%$ of total binding, was $3 \mu \mathrm{IU} \cdot \mathrm{mL}^{-1}$. For $\mathrm{GH}$, the intraassay $\mathrm{CV}$ was $15.3 \%$ at $2.5 \mathrm{ng} \cdot \mathrm{mL}^{-1}$, and average sensitivity was $0.75 \mathrm{ng} \cdot \mathrm{mL}^{-1}$. Plasma IGF-I concentrations were determined after an acid-ethanol extraction, which was validated for plasma samples from lactating and weaned sows [20]. The intra- and interassay $\mathrm{CV}$ were $7.4 \%$ and $17 \%$ at $258 \mathrm{ng} \cdot \mathrm{mL}^{-1}$, respectively, and average sensitivity was $7.5 \mathrm{ng} \cdot \mathrm{mL}^{-1}$. The results on porcine leptin are expressed in Human Equivalent (HE). The leptin intraassay $\mathrm{CV}$ was $5.0 \%$ at $4.1 \mathrm{ng} \mathrm{HE} \cdot \mathrm{mL}^{-1}$, and the average sensitivity of the assay was $0.9 \mathrm{ng}$ $\mathrm{HE} \cdot \mathrm{mL}^{-1}$. The prolactin intraassay $\mathrm{CV}$ was $3.5 \%$ at $50 \mathrm{ng} \cdot \mathrm{mL}^{-1}$ and the average sensitivity was $1.8 \mathrm{ng} \cdot \mathrm{mL}^{-1}$.

Concentrations were measured every $15 \mathrm{~min}$ from 0815 to $1615(\mathrm{GH})$, once a day (at 1400, IGF-I), twice a day (at 0815 and 
1530, leptin), around the morning meal (at 0830) and every $15 \mathrm{~min}$ from 0930 to 1030 (insulin) and on a pool of 3 samples collected at 0815, 1215 and 1615 (prolactin).

\subsection{Calculations and statistical analyses}

The total energy requirement of sows during lactation (TER, MJ ME· $\mathrm{d}^{-1}$ ) was calculated according to the formula of Noblet et al. [2]: TER $=0.46 \mathrm{BW}^{0.75}+$ 28.59 LWG $-0.52 n$, where BW $(\mathrm{kg})=$ sow body weight after farrowing, LWG $\left(\mathrm{g} \cdot \mathrm{d}^{-1}\right)=$ litter weight gain over lactation and $n=$ the number of piglets per litter on d 5 of lactation. Crude lysine requirement was estimated for a nil change in muscle weight over lactation $\left(\mathrm{CMW}, \mathrm{g} \cdot \mathrm{d}^{-1}\right.$ ) using the formula of Dourmad et al. [5]: CMW $=-525+$ 29.8 lysine $-0.392 \mathrm{LWG}\left(R^{2}=0.69\right)$. Energy and lysine balances were calculated by subtracting the calculated requirements from the actual intakes. The chemical composition of the body weight on 1 and 28 of lactation was estimated from the body weight and $\mathrm{P}_{2}$ measurements using the equations proposed by Dourmad et al. [24]: lipid $(\mathrm{kg})=-26.4+$ $0.221 \mathrm{EBW}+1.331 \mathrm{P}_{2}\left(R^{2}=0.95\right)$, protein $(\mathrm{kg})=2.28+0.178 \mathrm{EBW}-0.333 \mathrm{P}_{2}\left(R^{2}=\right.$ $0.87)$, where EBW $(\mathrm{kg})$ represents the sow empty live weight estimated from the live weight $\left(\mathrm{EBW}=0.905 \mathrm{BW}^{1.013}\right)$, and $\mathrm{P}_{2}$ the backfat thickness at the level of the last rib. The parity number (primiparous sows) and body weight at farrowing of sows in the current study were similar to those from which the equations were developed.

Statistical analyses of sow and litter performances were performed on data from the 38 sows allocated to experimental treatments and analyses of hormones and metabolites were done on data from the 24 catheterized sows. Data were analyzed according to a randomized complete block design, with three treatments in 4 replicates (blocks), with an analysis of variance using the MIXED procedure of SAS [25]. All models included the effects of the treatment (fixed effect) and of the replicate (random effect). All data for sow feed intake, litter growth rate, hormone and metabolites were analyzed using repeated measures in MIXED procedures. The complete model included treatment, replicate, time and time $\times$ treatment interaction as the main effects, sow was the experimental unit and significant differences among treatments were determined using sow within replicate $\times$ treatment interaction as the error term. The time effect was in weeks for litter growth and sow feed intake, days for mean concentrations of IGF-I, leptin and prolactin, or sampling time effect for metabolite, insulin and GH profiles. The results are presented as least squares means \pm standard errors.

\section{RESULTS}

\subsection{Litter performance}

Litter weight at farrowing $(15.2 \pm 0.6 \mathrm{~kg})$ and litter size throughout lactation $(9.3 \pm$ 0.3 piglets) were similar in the 3 groups of females $(P>0.1)$. There was no treatment $x$ week interaction for litter growth rate $(P>$ 0.1 ; Tab. II). Litters from $180 \mathrm{CP}$ sows grew faster $\left(1950 \pm 110 \mathrm{~g} \cdot \mathrm{d}^{-1}\right)$ than litters from 180LP $\left(1660 \pm 70 \mathrm{~g} \cdot \mathrm{d}^{-1} ; P<0.05\right)$ and 240LP $\left(1680 \pm 100 \mathrm{~g} \cdot \mathrm{d}^{-1} ; P<0.07\right)$ sows.

\subsection{Sow performance}

Feeding treatments during rearing and gestation resulted in sows that weighed around 180 (180CP and 180LP sows) or $240 \mathrm{~kg}$ (240LP sows) at the beginning of lactation (Tab. III). Backfat thickness was similar in the 180CP and 180LP sows but was greater $(P<0.05)$ in the 240LP sows (Tab. III). Estimated contents of the sow's body lipid and protein, expressed as a percentage of live weight, were also similar in the $180 \mathrm{CP}$ and 180LP sows (lipid: 15.7\%; protein: $16.3 \%)$ but were different $(P<0.001)$ in the 240LP sows (lipid: $22.5 \%$; protein: $15.3 \%$ ).

There was an interaction between treatment and week of lactation for feed intake (Tab. IV). Feed intake was lower $(P<0.05)$ for the 240LP than for the 180CP and 180LP 
Table II. Litter performance during lactation in experimental sows (LSMEANS \pm SEM).

\begin{tabular}{|c|c|c|c|}
\hline & \multicolumn{3}{|c|}{ Treatment $^{1}$} \\
\hline & $\begin{array}{c}180 \mathrm{CP} \\
(n=12)\end{array}$ & $\begin{array}{c}180 \mathrm{LP} \\
(n=12)\end{array}$ & $\begin{array}{c}240 \mathrm{LP} \\
(n=14)\end{array}$ \\
\hline \multicolumn{4}{|c|}{ Litter growth rate ${ }^{2}, \mathrm{~g} \cdot \mathrm{d}^{-1}$} \\
\hline Week 1 & $1393 \pm 96$ & $1262 \pm 96$ & $1197 \pm 89$ \\
\hline Week 2 & $2176 \pm 96$ & $1856 \pm 96$ & $1839 \pm 89$ \\
\hline Week 3 & $2218 \pm 96$ & $1875 \pm 96$ & $1917 \pm 89$ \\
\hline Week 4 & $2106 \pm 96$ & $1731 \pm 96$ & $1863 \pm 89$ \\
\hline
\end{tabular}

${ }^{1} 180 \mathrm{CP}$ and 180LP: sows weighing $180 \mathrm{~kg}$ at farrowing and fed a control or low-protein diet during lactation; 240LP: sows weighing $240 \mathrm{~kg}$ at farrowing and fed a low-protein diet.

2 Treatment effect: $P=0.02$, week effect: $P<0.001$, treatment $\times$ week interaction: $P=0.48$.

Table III. Changes in live weight, backfat thickness and estimated chemical composition in sows during lactation (LSMEANS \pm SEM).

\begin{tabular}{|c|c|c|c|c|}
\hline & \multicolumn{3}{|c|}{ Treatment $^{1}$} & \multirow[b]{2}{*}{$P$-value } \\
\hline & $\begin{array}{c}180 \mathrm{CP} \\
(n=12)\end{array}$ & $\begin{array}{c}180 \mathrm{LP} \\
(n=12)\end{array}$ & $\begin{array}{c}240 \mathrm{LP} \\
(n=14)\end{array}$ & \\
\hline \multicolumn{5}{|l|}{ Live weight, $\mathrm{kg}$} \\
\hline d 1 & $182.6 \pm 6.6^{\mathrm{a}}$ & $181.1 \pm 6.6^{\mathrm{a}}$ & $238.2 \pm 6.4^{b}$ & 0.001 \\
\hline d 28 & $163.2 \pm 5.5^{\mathrm{a}}$ & $159.0 \pm 5.5^{\mathrm{a}}$ & $200.5 \pm 5.3^{\mathrm{b}}$ & 0.001 \\
\hline Variation & $-19.4 \pm 3.6^{\mathrm{a}}$ & $-22.1 \pm 3.6^{\mathrm{a}}$ & $-37.6 \pm 3.4^{b}$ & 0.001 \\
\hline \multicolumn{5}{|l|}{ Backfat thickness, mm } \\
\hline d 1 & $12.3 \pm 0.9^{\mathrm{a}}$ & $12.0 \pm 0.9^{\mathrm{a}}$ & $21.6 \pm 0.8^{b}$ & 0.001 \\
\hline $\mathrm{d} 28$ & $9.0 \pm 0.6^{\mathrm{a}}$ & $10.2 \pm 0.6^{\mathrm{a}}$ & $16.3 \pm 0.5^{b}$ & 0.001 \\
\hline Variation & $-3.2 \pm 0.5^{\mathrm{a}}$ & $-1.9 \pm 0.5^{b}$ & $-5.3 \pm 0.5^{\mathrm{c}}$ & 0.001 \\
\hline \multicolumn{5}{|l|}{ Lipid $^{2}, \mathrm{~kg}$} \\
\hline d 1 & $29.1 \pm 1.8^{\mathrm{a}}$ & $28.5 \pm 1.8^{\mathrm{a}}$ & $53.6 \pm 1.8^{\mathrm{b}}$ & 0.001 \\
\hline $\mathrm{d} 28$ & $20.7 \pm 1.5^{\mathrm{a}}$ & $21.1 \pm 1.5^{\mathrm{a}}$ & $38.2 \pm 1.4^{\mathrm{b}}$ & 0.001 \\
\hline Variation & $-8.5 \pm 1.3^{\mathrm{a}}$ & $-7.4 \pm 1.3^{\mathrm{a}}$ & $-15.3 \pm 1.2^{b}$ & 0.001 \\
\hline Loss, $\%$ lipid mass at $\mathrm{d} 1$ & $29.2 \pm 2.1$ & $25.8 \pm 1.3$ & $28.5 \pm 2.1$ & 0.46 \\
\hline \multicolumn{5}{|l|}{ Protein $^{2}, \mathrm{~kg}$} \\
\hline d 1 & $29.6 \pm 1.2^{\mathrm{a}}$ & $29.6 \pm 1.2^{\mathrm{a}}$ & $36.4 \pm 1.2^{b}$ & 0.001 \\
\hline d 28 & $27.3 \pm 1.0^{\mathrm{a}}$ & $26.2 \pm 1.0^{\mathrm{a}}$ & $31.5 \pm 1.0^{\mathrm{b}}$ & 0.001 \\
\hline Variation & $-2.4 \pm 0.6^{\mathrm{a}}$ & $-3.3 \pm 0.6^{\mathrm{a}}$ & $-4.9 \pm 0.6^{b}$ & 0.002 \\
\hline Loss, $\%$ protein mass at $\mathrm{d} 1$ & $8.2 \pm 1.0^{\mathrm{a}}$ & $11.1 \pm 1.1^{\mathrm{ab}}$ & $13.5 \pm 1.6^{\mathrm{b}}$ & 0.016 \\
\hline
\end{tabular}

${ }_{1}^{1} 180 \mathrm{CP}$ and 180LP: sows weighing $180 \mathrm{~kg}$ at farrowing and fed a control or low-protein diet during lactation; 240LP: sows weighing $240 \mathrm{~kg}$ at farrowing and fed a low-protein diet.

2 The chemical composition of sows was estimated from the body weight and backfat thickness measurements using the equations proposed by Dourmad et al. [24]: lipids $(\mathrm{kg})=-26.4+0.221 \mathrm{EBW}+1.331$ $\mathrm{P}_{2}$, protein $(\mathrm{kg})=2.28+0.178 \mathrm{EBW}-0.333 \mathrm{P}_{2}$, where $\mathrm{EBW}(\mathrm{kg})$ represents the sow empty live weight $\left(\mathrm{EBW}=0.905 \mathrm{BW}^{1.013}, \mathrm{BW}=\right.$ live weight in $\left.\mathrm{kg}\right)$ and $\mathrm{P}_{2}(\mathrm{~mm})=$ backfat thickness at the level of the last rib. a,b,c Within a row, means without a common superscript letter differ $(P<0.05)$. 
Table IV. Feed, energy and lysine intakes of sows during lactation (LSMEANS \pm SEM).

\begin{tabular}{lccccc}
\hline & \multicolumn{5}{c}{ Treatment $^{1}$} \\
\cline { 2 - 4 } & $\begin{array}{c}180 \mathrm{CP} \\
(n=12)\end{array}$ & $\begin{array}{c}180 \mathrm{LP} \\
(n=12)\end{array}$ & $\begin{array}{c}240 \mathrm{LP} \\
(n=14)\end{array}$ & Effect $^{2}$ & $P$-value \\
\hline Feed intake, $\mathrm{kg} \cdot \mathrm{d}^{-1}$ & $3.6 \pm 0.2^{\mathrm{a} \cdot \mathrm{x}}$ & $3.9 \pm 0.2^{\mathrm{a}}$ & $2.5 \pm 0.2^{\mathrm{b} . \mathrm{x}}$ & $\mathrm{T}$ & 0.03 \\
$\quad$ Week 1 & $4.2 \pm 0.2^{\mathrm{a} . \mathrm{y}}$ & $4.2 \pm 0.2^{\mathrm{a}}$ & $3.5 \pm 0.2^{\mathrm{b} . \mathrm{y}}$ & $\mathrm{W}$ & 0.001 \\
Week 2 & $4.3 \pm 0.2^{\mathrm{y}}$ & $4.3 \pm 0.2$ & $3.9 \pm 0.2^{\mathrm{z}}$ & $\mathrm{T} \times \mathrm{W}$ & 0.03 \\
Week 3 & $4.3 \pm 0.2^{\mathrm{y}}$ & $4.3 \pm 0.2$ & $4.1 \pm 0.2^{\mathrm{z}}$ & & \\
Week 4 & $4.1 \pm 0.1$ & $4.2 \pm 0.1$ & $3.5 \pm 0.3$ & $\mathrm{~T}$ & 0.05 \\
Weeks 1-4 & $53.1 \pm 2.5^{\mathrm{a}}$ & $54.8 \pm 2.5^{\mathrm{a}}$ & $45.6 \pm 2.1^{\mathrm{b}}$ & $\mathrm{T}$ & 0.02 \\
ME intake, MJ.d $\mathrm{d}^{-1}$ & $39.4 \pm 1.1^{\mathrm{a}}$ & $21.6 \pm 1.1^{\mathrm{b}}$ & $16.0 \pm 1.0^{\mathrm{c}}$ & $\mathrm{T}$ & 0.001 \\
\hline Lysine intake, $\mathrm{g} \cdot \mathrm{d}^{-1}$ & & &
\end{tabular}

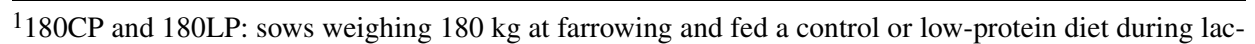
tation; 240LP: sows weighing $240 \mathrm{~kg}$ at farrowing and fed a low-protein diet.

$2 \mathrm{~T}=$ treatment effect; $\mathrm{W}=$ week effect; $\mathrm{T} \times \mathrm{W}=$ treatment $\times$ week interaction

a,b,c Within a row, means without a common superscript letter differ $(P<0.05)$.

$\mathrm{x}, \mathrm{y}, \mathrm{z}$ Within a column, means without a common superscript letter differ $(P<0.05)$.

sows during the first and second weeks of lactation. Average daily feed intake over lactation was close to that initially planned for the 180CP and 180LP sows $\left(4.1 \mathrm{~kg} \cdot \mathrm{d}^{-1}\right)$, but was lower than expected for the 240LP sows $\left(3.5 \mathrm{~kg} \cdot \mathrm{d}^{-1}\right)$. As a consequence, the 240LP sows ingested $14 \%$ less daily metabolizable energy and 59\% less lysine $(P<$ $0.05)$ than the $180 \mathrm{CP}$, whereas the $180 \mathrm{LP}$ sows ingested $3 \%$ more energy $(P>0.1)$ and $45 \%$ less lysine $(P<0.05)$ than the 180CP sows (Tab. IV).

During lactation, the 240LP sows lost more body weight than the other sows $(P<$ 0.05 , Tab. III). Backfat loss in lactation differed $(P<0.001)$ between the 3 groups: it was high in the 240LP sows, low in the $180 \mathrm{LP}$ sows and intermediate in the $180 \mathrm{CP}$. The estimated contents of the sow's body lipids and proteins at farrowing and at weaning and losses during lactation did not differ between the 180CP and 180LP sows but were all greater in the 240LP sows $(P<$ $0.05)$. Losses of fat tissue represented on average $28 \%$ of body lipid mass at farrowing for all sows $(P>0.1)$. Losses of body protein, as a percentage of protein mass at farrowing, were higher $(P<0.05)$ in the $240 \mathrm{LP}$ than in the $180 \mathrm{CP}$ sows and interme- diate in the 180LP sows. Despite a greater mobilization of body reserves during lactation, the 240LP sows were still heavier and fattier at weaning than the $180 \mathrm{CP}$ and $180 \mathrm{LP}$ sows $(P<0.05$; Tab. III $)$.

Estimated daily energy requirements for maintenance and milk production did not significantly differ between treatments (Tab. V). All sows had a negative energy balance during lactation, but this was more pronounced in the 240LP and 180CP sows than in the 180LP sows. The lysine balance was slightly negative for the $180 \mathrm{CP}$ sows and strongly negative for protein-restricted sows, being more negative $(P<0.05)$ in the $240 \mathrm{LP}$ than in the 180LP sows.

\subsection{Physiological parameters}

\subsubsection{AA concentrations on day $W-1$}

There was no treatment $\times$ sampling time interaction for histidine, glutamine, alanine and proline (Tab. VI). Plasma concentrations of proline were not influenced by treatments but increased after the meal. Concentrations of histidine, glutamine and alanine were higher $(P<0.001)$ in protein-restricted sows, whatever the sampling time. There was a 
Table V. Energy and lysine balance during lactation in sows (LSMEANS \pm SEM).

\begin{tabular}{|c|c|c|c|c|}
\hline & \multicolumn{3}{|c|}{ Treatment $^{1}$} & \multirow[b]{2}{*}{$P$-value } \\
\hline & $\begin{array}{c}180 \mathrm{CP} \\
(n=12)\end{array}$ & $\begin{array}{c}180 \mathrm{LP} \\
(n=12)\end{array}$ & $\begin{array}{c}240 \mathrm{LP} \\
(n=14)\end{array}$ & \\
\hline ME requirements ${ }^{2}, \mathrm{MJ} \cdot \mathrm{d}^{-1}$ & $73.2 \pm 3.3$ & $65.2 \pm 2.9$ & $71.1 \pm 2.9$ & 0.110 \\
\hline ME balance, $\mathrm{MJ} \cdot \mathrm{d}^{-1}$ & $-20.1 \pm 3.3^{\mathrm{a}}$ & $-10.4 \pm 3.3^{b}$ & $-25.5 \pm 3.3^{\mathrm{a}}$ & 0.001 \\
\hline Lysine balance ${ }^{3}, \mathrm{~g} \cdot \mathrm{d}^{-1}$ & $-6.6 \pm 1.1^{\mathrm{a}}$ & $-21.8 \pm 1.1^{\mathrm{b}}$ & $-27.4 \pm 1.0^{\mathrm{c}}$ & 0.001 \\
\hline
\end{tabular}

${ }^{1} 180 \mathrm{CP}$ and 180LP: sows weighing $180 \mathrm{~kg}$ at farrowing and fed a control or low-protein diet during lactation; 240LP: sows weighing $240 \mathrm{~kg}$ at farrowing and fed a low-protein diet.

${ }^{2}$ Total metabolizable energy (ME) requirements of sows during lactation (TER) were estimated according to the formula of Noblet et al. [2]: TER $\left(\mathrm{MJ} \mathrm{ME} \cdot \mathrm{d}^{-1}\right)=0.46 \times$ body weight $^{0.75}+28.59 \times$ litter weight gain $-0.52 \times$ number of piglets.

${ }^{3}$ Mean lysine estimated requirement of sows during lactation was $46.0 \mathrm{~g} / \mathrm{d}$ for the $180 \mathrm{CP}$ sows and $43.4 \mathrm{~g} \cdot \mathrm{d}^{-1}$ for the 180LP and 240LP sows. It was estimated using the equation proposed by Dourmad et al. [5] for a nil muscle weight change: $-525+29.8$ lysine -0.392 litter weight gain.

a,b,c Within a row, means without a common superscript letter differ $(P<0.05)$.

treatment $\times$ sampling time interaction for other AA. Before the morning meal, the 240LP sows had greater $(P<0.05)$ concentrations of lysine and phenylalanine compared with the 180CP and 180LP sows and higher concentrations of tryptophan and LNAA compared with the 180LP sows. The concentrations of valine were lower in the $180 \mathrm{LP}$ sows than in the sows from the other groups. Protein-restricted sows (180LP and 240LP) had higher concentrations of threonine, methionine, serine and asparagine $(P<$ 0.05 ; Tab. VI). After feeding, plasma concentrations of most AA increased significantly in sows not-restricted, while variations were observed in protein-restricted sows (increase, decrease or no change, depending on the AA). As a consequence, the 180LP and 240LP sows had significantly lower postprandial concentrations of most AA, including LNAA, than the 180CP sows. They also had a higher Try/LNAA ratio (Tab. VI).

\subsubsection{NEFA, urea, $\alpha$-amino nitrogen}

On days $\mathrm{W}-1$ and $\mathrm{W}+1$, plasma concentrations of NEFA were high before the morning meal and decreased afterwards $(P<0.003)$. They were not influenced by treatments on day $\mathrm{W}-1\left(961 \pm 157\right.$ and $153 \pm 159 \mu \mathrm{mol} \cdot \mathrm{L}^{-1}$ at 0815 and 1215 , respectively) and day $\mathrm{W}+1(298 \pm 35$ and $116 \pm 34$ at 0815 and
1215 , Fig. 1). On day $\mathrm{W}-1$, the urea/ $\alpha$-amino nitrogen ratio was greater in the $180 \mathrm{CP}$ than in the 180LP and 240LP sows, regardless of the sampling time (Fig. 2). It did not differ between treatments after weaning.

\subsubsection{Glucose and insulin}

Meal-related profiles of glucose and insulin on days $\mathrm{W}-1$ and $\mathrm{W}+1$ are presented in figures 3 and 4 . For glucose, there was a treatment $\times$ sampling time interaction on day W-1 (Fig. 3). Concentrations of glucose were similar in the 3 groups of females before the morning meal. One hour after distribution of the meal, they were greater $(P<0.05)$ in the 240LP and 180CP than in the 180LP sows. Glucose concentrations remained higher in the 240LP sows 75 and $90 \mathrm{~min}$ after the meal. On day $\mathrm{W}+1$, glucose profiles and concentrations were similar in the 3 groups (Fig. 3).

There was no treatment $\times$ sampling time interaction on the concentrations of insulin on day $\mathrm{W}-1$, but there were treatment and sampling time effects. Insulin concentrations were low before the morning meal and increased after the meal in all sows. From 60 to 120 min after feed distribution, mean concentrations were higher in the 240LP than in the 180LP sows and intermediate in the 180CP sows $(P<0.05$, Fig. 4$)$. On day 
Table VI. Pre- and postprandial plasma amino acid concentrations in sows $1 \mathrm{~d}$ before weaning $(n=8$ per treatment group).

\begin{tabular}{|c|c|c|c|c|c|c|c|c|c|c|}
\hline \multirow{2}{*}{ Amino acid, $\mathrm{nmol} \cdot \mathrm{mL}^{-1}$} & \multicolumn{3}{|c|}{ Preprandial (0815) } & \multicolumn{4}{|c|}{ Postprandial (1400) } & \multicolumn{3}{|c|}{$P$-value ${ }^{2}$} \\
\hline & $180 \mathrm{CP}$ & $180 \mathrm{LP}$ & $240 \mathrm{LP}^{1}$ & $180 \mathrm{CP}$ & $180 \mathrm{LP}$ & $240 \mathrm{LP}^{1}$ & SEM & $\mathrm{T}$ & $\mathrm{S}$ & $\mathrm{T} \times \mathrm{S}$ \\
\hline \multicolumn{11}{|l|}{ Essential AA } \\
\hline Lysine & $51^{\mathrm{v}}$ & $69^{v}$ & $129^{x}$ & $147^{x}$ & $108^{x}$ & $122^{x}$ & 14 & 0.11 & 0.001 & 0.001 \\
\hline Arginine & $45^{\mathrm{v}}$ & $57^{v}$ & $69^{v}$ & $149^{\mathrm{x}}$ & $62^{\mathrm{v}}$ & $58^{v}$ & 8 & 0.001 & 0.001 & 0.001 \\
\hline Leucine & $89^{v}$ & $90^{\mathrm{v}}$ & $106^{\mathrm{V}}$ & $160^{\mathrm{x}}$ & $97^{\mathrm{v}}$ & $89^{v}$ & 9 & 0.005 & 0.007 & 0.001 \\
\hline Valine & $131^{\mathrm{v}}$ & $94^{\mathrm{x}}$ & $124^{\mathrm{V}}$ & $219^{z}$ & $66^{y}$ & $68^{y}$ & 9 & 0.001 & 0.83 & 0.001 \\
\hline Isoleucine & $56^{\mathrm{vx}}$ & $50^{\mathrm{v}}$ & $68^{x}$ & $105^{y}$ & $28^{\mathrm{z}}$ & $26^{\mathrm{Z}}$ & 5 & 0.001 & 0.16 & 0.001 \\
\hline Threonine & $74^{v}$ & $118^{\mathrm{x}}$ & $133^{x y}$ & $197^{\mathrm{z}}$ & $156^{\mathrm{y}}$ & $156^{\mathrm{y}}$ & 15 & 0.89 & 0.001 & 0.001 \\
\hline Phenylalanine & $38^{v}$ & $43^{v}$ & $57^{\mathrm{x}}$ & $97 \mathrm{y}$ & $55^{\mathrm{x}}$ & $54^{\mathrm{x}}$ & 3 & 0.001 & 0.001 & 0.001 \\
\hline Tryptophan & $18^{\mathrm{vx}}$ & $16^{\mathrm{v}}$ & $22^{x}$ & $37 y$ & $30^{\mathrm{z}}$ & $27^{\mathrm{z}}$ & 2 & 0.12 & 0.001 & 0.002 \\
\hline Histidine & 58 & 82 & 85 & 71 & 84 & 89 & 4 & 0.001 & 0.03 & 0.22 \\
\hline Methionine & $21^{\mathrm{v}}$ & $35^{\mathrm{x}}$ & $36^{\mathrm{x}}$ & $48^{y}$ & $36^{\mathrm{x}}$ & $38^{\mathrm{x}}$ & 3 & 0.76 & 0.001 & 0.001 \\
\hline \multicolumn{11}{|l|}{ Nonessential AA } \\
\hline Glutamine & 710 & 966 & 860 & 758 & 1114 & 1099 & 48 & 0.001 & 0.001 & 0.11 \\
\hline Proline & 142 & 188 & 144 & 318 & 334 & 286 & 29 & 0.15 & 0.001 & 0.85 \\
\hline Alanine & 211 & 495 & 355 & 385 & 577 & 502 & 40 & 0.001 & 0.001 & 0.36 \\
\hline Serine & $78^{v}$ & $110^{\mathrm{x}}$ & $107^{x}$ & $122^{\mathrm{x}}$ & $121^{\mathrm{x}}$ & $106^{x}$ & 7 & 0.15 & 0.001 & 0.002 \\
\hline Glycine & $664^{\mathrm{v}}$ & $1000^{x}$ & $717^{\mathrm{vy}}$ & $874^{x y}$ & $984^{x y}$ & $809^{v x y}$ & 83 & 0.08 & 0.01 & 0.05 \\
\hline Asparagine & $41^{\mathrm{v}}$ & $69^{x y}$ & $61^{x}$ & $160^{\mathrm{z}}$ & $80^{y}$ & $72^{x y}$ & 6 & 0.001 & 0.001 & 0.001 \\
\hline Tyrosine & $31^{\mathrm{vx}}$ & $27^{\mathrm{v}}$ & $30^{\mathrm{vx}}$ & $96^{y}$ & $39^{x}$ & $30^{\mathrm{vx}}$ & 5 & 0.001 & 0.001 & 0.001 \\
\hline Cystine & $52^{\mathrm{v}}$ & $55^{\mathrm{vx}}$ & $60^{x}$ & $58^{\mathrm{vx}}$ & $52^{\mathrm{v}}$ & $55^{\mathrm{vx}}$ & 3 & 0.40 & 0.60 & 0.03 \\
\hline \multicolumn{11}{|l|}{ Balance } \\
\hline LNAA $^{3}$ & $345^{\mathrm{vx}}$ & $304^{v y}$ & $386^{\mathrm{x}}$ & $676^{z}$ & $285^{\mathrm{vy}}$ & $267 y$ & 24 & 0.001 & 0.004 & 0.001 \\
\hline Tyr/LNAA ${ }^{4}$ & 11 & 10 & 8 & 17 & 16 & 13 & 1 & 0.09 & 0.001 & 0.45 \\
\hline Try/LNAA ${ }^{5}$ & $5^{v}$ & $6^{v}$ & $6^{v}$ & $6^{v}$ & $11^{\mathrm{x}}$ & $11^{\mathrm{x}}$ & 1 & 0.001 & 0.001 & 0.001 \\
\hline
\end{tabular}

${ }^{1} 180 \mathrm{CP}$ and 180LP: sows weighing $180 \mathrm{~kg}$ at farrowing and fed a control or low-protein diet during lactation; 240LP: sows weighing $240 \mathrm{~kg}$ at farrowing and fed a low-protein diet.

${ }^{2} \mathrm{~T}=$ treatment effect; $\mathrm{S}=$ sampling time effect; $\mathrm{T} \times \mathrm{S}=$ treatment $\times$ sampling time interaction.

${ }^{3}$ Large neutral AA: isoleucine + leucine + valine + phenylalanine + tyrosine.

${ }^{4} \mathrm{Tyr} / \mathrm{LNAA}=$ tyrosine $/($ isoleucine + leucine + valine + phenylalanine + tryptophan $) ; \times 100$.

5 Try/LNAA $=$ tryptophan $/$ LNAA; $\times 100$.

$\mathrm{v}, \mathrm{x}, \mathrm{y}, \mathrm{z}$ Within a row, means without a common superscript letter differ $(P<0.05)$.

$\mathrm{W}+1$, the profiles and concentrations of insulin did not differ between treatments and the concentrations were lower than at the end of lactation $(P<0.001)$.

\subsubsection{GH, IGF-I and GH/IGF-I ratio}

Representative profiles of plasma GH on days $\mathrm{W}-1$ and $\mathrm{W}+1$ are presented in Figure 5.
On day $\mathrm{W}-1$, the profiles of GH were influenced by sampling time $(P<0.001)$ and treatment $(P=0.051)$, with the $\mathrm{GH}$ concentrations being greater $(P<0.05)$ in the $180 \mathrm{LP}$ $\left(9.5 \pm 0.9 \mathrm{ng} \cdot \mathrm{mL}^{-1}\right)$ than in the $180 \mathrm{CP}$ sows $\left(7.2 \pm 0.9 \mathrm{ng} \cdot \mathrm{mL}^{-1}\right)$ and intermediate in the 240LP sows $\left(8.0 \pm 0.9 \mathrm{ng} \cdot \mathrm{mL}^{-1}\right)$. On day $\mathrm{W}+1$, the profiles were not affected by treatment or sampling time $(P>0.1)$. 


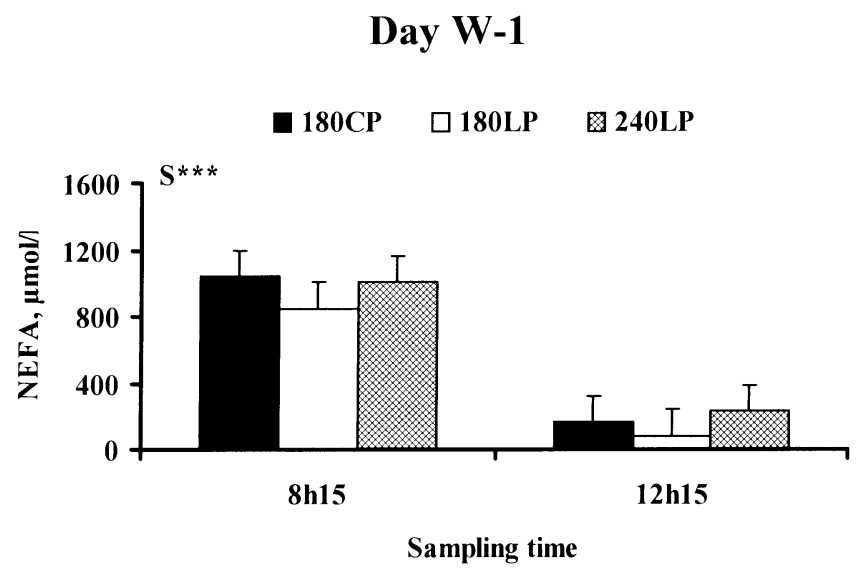

Day W+1

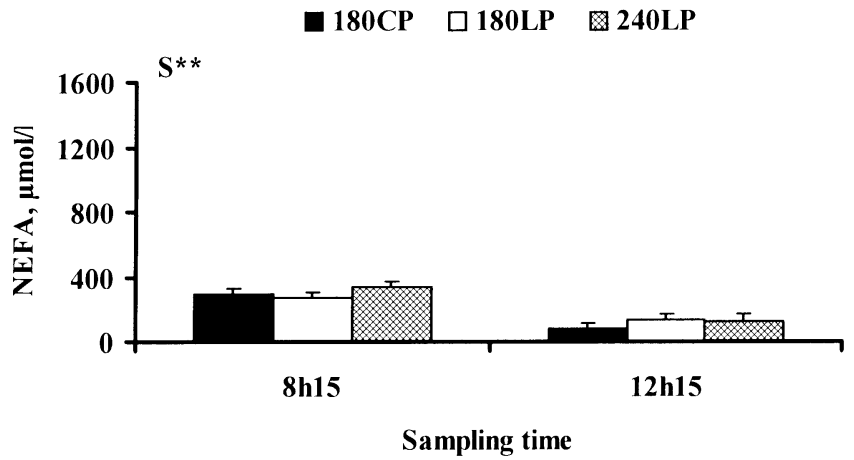

Figure 1. Plasma concentrations of non-esterified fatty acids (NEFA) $1 \mathrm{~d}$ before (W-1) and after $(\mathrm{W}+1)$ weaning in sows (180CP and 180LP: sows weighing $180 \mathrm{~kg}$ at farrowing and fed a control or low-protein diet during lactation; 240LP: sows weighing $240 \mathrm{~kg}$ at farrowing and fed a lowprotein diet). $\mathrm{S}$ indicates sampling time effect. $* * * P<0.001, * * P<0.01$.

On days $\mathrm{W}-1$ and $\mathrm{W}+1$, there were treatment and sampling day effects on the IGF-I concentrations (Tab. III). Plasma concentrations of IGF-I were reduced $(P<0.001)$ in the 180LP sows compared to the sows from the other treatments. They decreased between day $\mathrm{W}-1$ and day $\mathrm{W}+1$ in all sows. The GH/IGF-I ratio was greater in the 180LP than in the other sows on day W-1 and did not differ between treatments on day $\mathrm{W}+1$ (Tab. III).

\subsubsection{Leptin}

There was a treatment $\times$ sampling day interaction for pre- and post-prandial concentrations of leptin on days $\mathrm{W}-1$ and $\mathrm{W}+1$. Preprandial concentrations did not significantly differ between groups on the day before weaning and increased after weaning in the 240LP sows only $(P<0.05)$. Postprandial concentrations were higher in the 240LP sows on the day before weaning and 

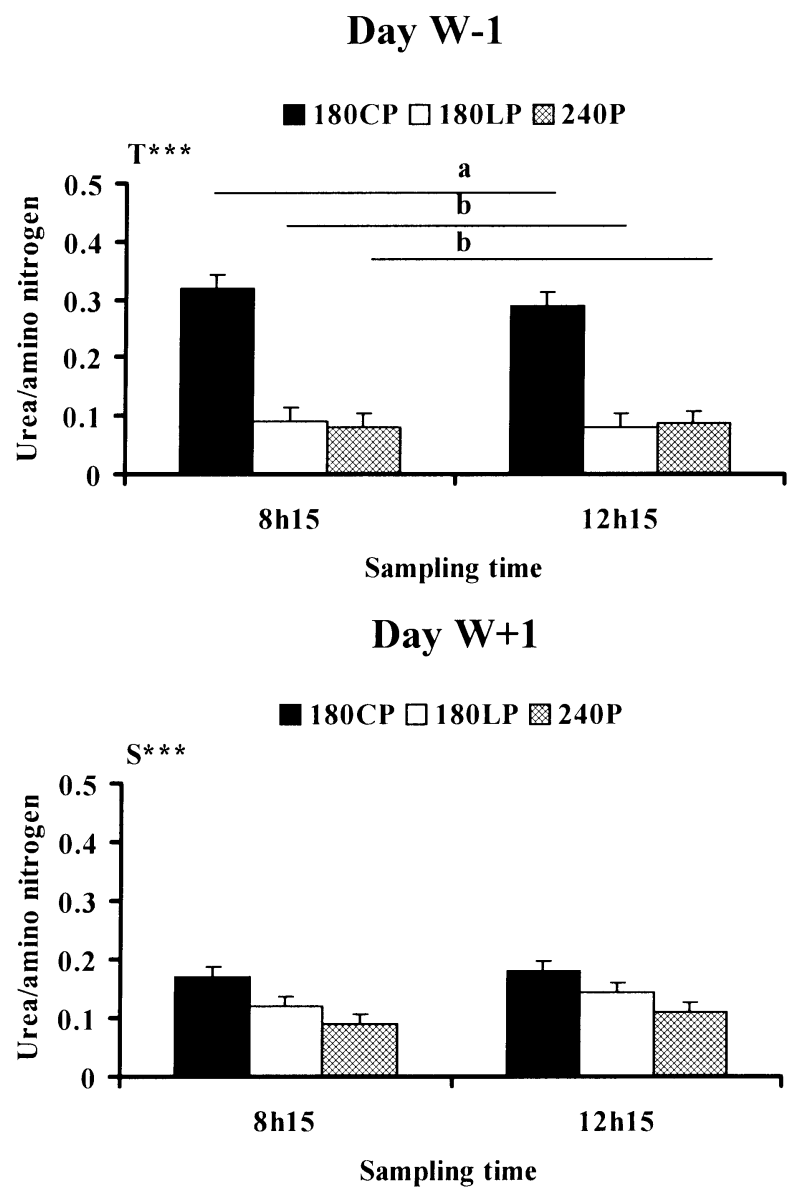

Figure 2. Ratio of plasma concentrations of urea to plasma concentrations of alpha-amino nitrogen, $1 \mathrm{~d}$ before $(\mathrm{W}-1)$ and after $(\mathrm{W}+1)$ weaning in sows (180CP and 180LP: sows weighing $180 \mathrm{~kg}$ at farrowing and fed a control or low-protein diet during lactation; 240LP: sows weighing $240 \mathrm{~kg}$ at farrowing and fed a low-protein diet). $\mathrm{T}$ and $\mathrm{S}$ indicate treatment and sampling time effects, respectively. $* * * P<0.001$. $^{\text {a,b }}$ Means without a common superscript letter differ $(P<0.05)$.

increased after weaning only in this group (Tab. VII).

\subsubsection{Prolactin}

Plasma concentrations of prolactin were not affected by treatments on days $\mathrm{W}-1$ or $\mathrm{W}+1$. They dropped after weaning in all females (Tab. VII).

\section{DISCUSSION}

Current findings indicate that the metabolic response to dietary protein restriction varies according to sow body reserves at farrowing.

In the present study, feed allowance was limited throughout lactation to prevent expectable differences in feed and energy intakes 
Day W-1

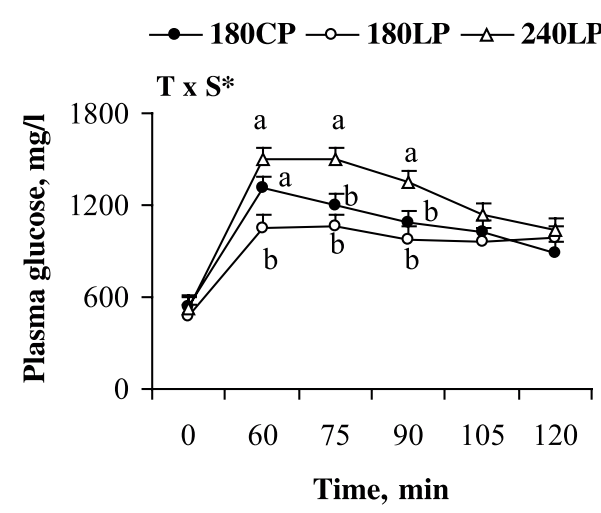

Day W+1

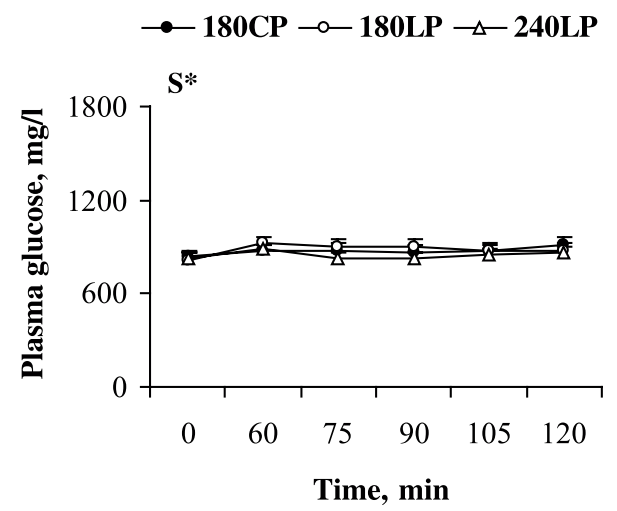

Figure 3. Plasma concentrations of glucose $1 \mathrm{~d}$ before $(\mathrm{W}-1)$ and after $(\mathrm{W}+1)$ weaning in primiparous sows (180CP and 180LP: sows weighing $180 \mathrm{~kg}$ at farrowing and fed a control or low-protein diet during lactation; 240LP: sows weighing $240 \mathrm{~kg}$ at farrowing and fed a low-protein diet). Time 0 indicates time of feeding. $T \times S$ indicates a treatment $\times$ sampling time interaction $(P<0.03)$ and $\mathrm{S}$ a sampling time effect $(P<$ $0.05)$. ${ }^{\mathrm{a}, \mathrm{b}}$ For each sampling time, means without a common superscript letter differ $(P<0.05)$.

among treatments, since voluntary ingestion during lactation is negatively related to backfat thickness at farrowing [26, 27] and may be reduced when the level of crude protein in the diet decreases below 12\% [28]. Despite this restriction, heavy sows (240LP), that
Day W-1

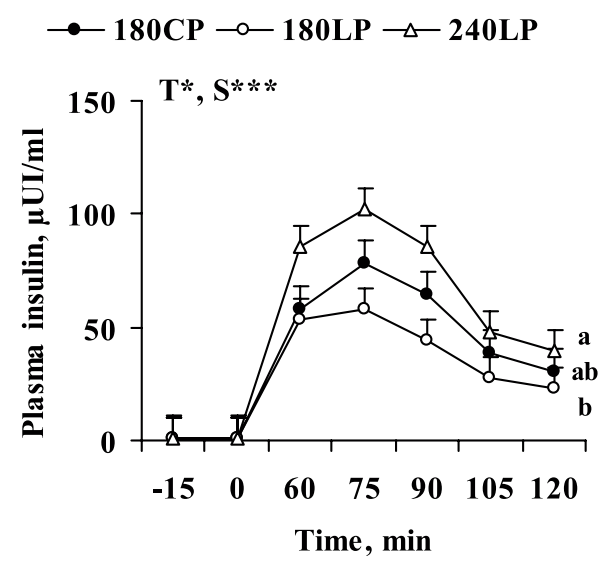

\section{Day W+1}

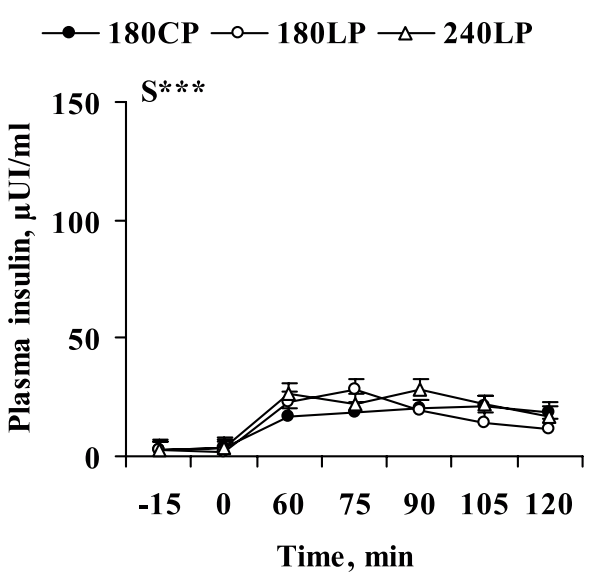

Figure 4. Plasma concentrations of insulin $1 \mathrm{~d}$ before $(\mathrm{W}-1)$ and after $(\mathrm{W}+1)$ weaning in primiparous sows (180CP and 180LP: sows weighing $180 \mathrm{~kg}$ at farrowing and fed a control or low-protein diet during lactation; 240LP: sows weighing $240 \mathrm{~kg}$ at farrowing and fed a low-protein diet). Time 0 indicates time of feeding. $\mathrm{T}$ and $\mathrm{S}$ indicate a treatment effect $(P<0.05)$ and a sampling time effect $(P<0.001)$, respectively. a,b Profiles without a common superscript letter differ $(P<0.05)$.

were also fattier, ate less than the lighter sows during the first and second weeks of lactation. 


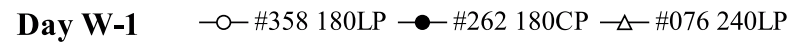

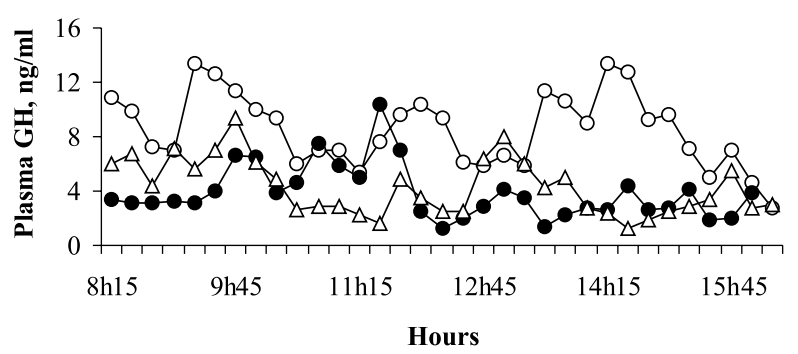

Day W+1 $\multimap-\# 358$ 180LP — \#262 180CP $\neg-\# 076240 \mathrm{LP}$

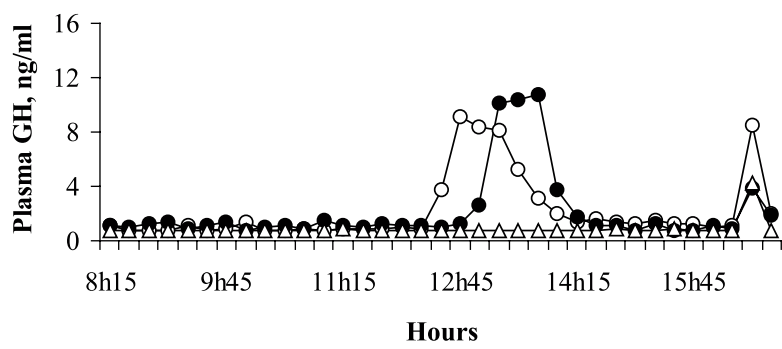

Figure 5. Representative plasma GH profiles $1 \mathrm{~d}$ before $(\mathrm{W}-1)$ and $1 \mathrm{~d}$ after $(\mathrm{W}+1)$ weaning in sows \#358 (group180LP), \#262 (group 180CP) and \#076 (group 240LP); 180CP and 180LP: sows weighing $180 \mathrm{~kg}$ at farrowing and fed a control or low-protein diet during lactation; 240LP: sows weighing $240 \mathrm{~kg}$ at farrowing and fed a low-protein diet.

The negative relationship between fat mass at farrowing and feed intake during lactation has been attributed, at least in part, to the greater state of insulin resistance reported in early or mid lactation in sows that are overfed during gestation $[29,30]$ or rearing [31]. In the present experiment, postprandial concentrations of insulin and glucose were clearly higher in the 240LP than in the 180LP sows despite similar intakes at the morning meal (intakes in the 240LP and 180LP sows, respectively: 29.7 and $28 \mathrm{MJ}$ ME; 209 and $205 \mathrm{~g} \mathrm{CP} ; 1498$ and $1421 \mathrm{~g}$ carbohydrates). This suggests an insulin resistant state in these heavy sows; however, glucose tolerance or meal tests are needed to confirm this. Nevertheless, insulin resistance is likely involved in the lower appetite of the 240LP sows.

The poor appetite of fat sows was also suggested to be related to concentrations of leptin, a hormone produced by adipose tissue, which inhibits appetite in pigs [32] and other mammals. Leptin concentrations at farrowing are greater in sows overfed during gestation than in sows conventionally fed, and decrease progressively or rapidly during lactation $[33,34]$. In the present study, the lack of treatment effects on pre- and postprandial leptin concentrations between treatment groups in late lactation suggests that the relationship between fat thickness and leptin is no longer apparent by the end of lactation, as previously observed by Estienne et al. [34]. Yet, leptin could still be involved in the control of appetite during the first and second weeks of lactation when feed intake was actually reduced.

The reduced appetite in early lactation led to energy and lysine balances being more negative in the 240LP than in the 180LP sows. However, the difference in lysine intake 
Table VII. Influence of treatments on plasma concentrations of mean GH, IGF-I, leptin and prolactin $1 \mathrm{~d}$ before $(\mathrm{W}-1)$ or after $(\mathrm{W}+1)$ weaning $(\mathrm{LSMEANS} \pm \mathrm{SEM})$.

\begin{tabular}{|c|c|c|c|c|c|c|}
\hline & \multicolumn{3}{|c|}{ Treatment $^{1}$} & \multicolumn{3}{|c|}{$P$-value ${ }^{2}$} \\
\hline & $\begin{array}{l}180 \mathrm{CP} \\
(n=8)\end{array}$ & $\begin{array}{l}180 \mathrm{LP} \\
(n=8)\end{array}$ & $\begin{array}{l}240 \mathrm{LP} \\
(n=8)\end{array}$ & $\mathrm{T}$ & D & $\mathrm{T} \times \mathrm{D}$ \\
\hline \multicolumn{7}{|c|}{ Plasma IGF-I, ng $\cdot \mathrm{mL}^{-1}$} \\
\hline $\mathrm{W}-1$ & $129.5 \pm 9.7$ & $91.1 \pm 9.7$ & $139.1 \pm 9.7$ & 0.004 & 0.001 & 0.72 \\
\hline $\mathrm{W}+1$ & $113.6 \pm 4.7$ & $75.2 \pm 9.7$ & $115.0 \pm 9.7$ & & & \\
\hline \multicolumn{7}{|c|}{ GH/IGF-I ratio } \\
\hline $\mathrm{W}-1$ & $0.06^{\mathrm{a}}$ & $0.11^{\mathrm{b}}$ & $0.06^{\mathrm{a}}$ & 0.001 & 0.001 & 0.045 \\
\hline $\mathrm{W}+1$ & $0.02^{\mathrm{a}}$ & $0.03^{\mathrm{a}}$ & $0.015^{\mathrm{a}}$ & & & \\
\hline \multicolumn{7}{|c|}{ Preprandial leptin (at 0815 ), ng $\cdot \mathrm{mL}^{-1}$} \\
\hline $\mathrm{W}-1$ & $1.9 \pm 0.1^{\mathrm{a}}$ & $1.9 \pm 0.1^{\mathrm{a}}$ & $2.1 \pm 0.1^{\mathrm{a}}$ & 0.001 & 0.001 & 0.001 \\
\hline $\mathrm{W}+1$ & $1.8 \pm 0.1^{\mathrm{a}}$ & $2.2 \pm 0.1^{\mathrm{a}}$ & $2.6 \pm 0.1^{b}$ & & & \\
\hline \multicolumn{7}{|c|}{ Postprandial leptin (at 1350 ), $\mathrm{ng} \cdot \mathrm{mL}^{-1}$} \\
\hline $\mathrm{W}-1$ & $1.9 \pm 0.1^{\mathrm{a}}$ & $1.9 \pm 0.1^{\mathrm{a}}$ & $2.4 \pm 0.1^{\mathrm{a}}$ & 0.001 & 0.001 & 0.001 \\
\hline $\mathrm{W}+1$ & $1.9 \pm 0.1^{\mathrm{a}}$ & $2.2 \pm 0.1^{\mathrm{a}}$ & $3.0 \pm 0.1^{\mathrm{b}}$ & & & \\
\hline \multicolumn{7}{|c|}{ Prolactin, $\mathrm{ng} \cdot \mathrm{mL}^{-1}$} \\
\hline $\mathrm{W}-1$ & $13.1 \pm 1.0$ & $14.4 \pm 1.4$ & $16.1 \pm 1.7$ & 0.41 & 0.001 & 0.26 \\
\hline $\mathrm{W}+1$ & $2.9 \pm 0.3$ & $2.5 \pm 0.2$ & $2.5 \pm 0.1$ & & & \\
\hline
\end{tabular}

${ }^{1} 180 \mathrm{CP}$ and 180LP: sows weighing $180 \mathrm{~kg}$ at farrowing and fed a control or low-protein diet during lactation; 240LP: sows weighing $240 \mathrm{~kg}$ at farrowing and fed a low-protein diet.

${ }^{2} \mathrm{~T}=$ treatment effect; $\mathrm{D}=$ sampling day effect; $\mathrm{T} \times \mathrm{D}=$ treatment $\times$ sampling day interaction.

${ }^{\mathrm{a}, \mathrm{b}}$ Means without a common superscript letter differ $(P<0.05)$.

and lysine balance between the 240LP and $180 \mathrm{LP}$ sows was low compared to that between $240 \mathrm{LP}$ and $180 \mathrm{CP}$ or between 180LP and 180CP. All sows had a negative energy balance and therefore mobilized both fat and protein reserves. Even sows receiving the high-protein diet (180CP) lost a relatively high amount of protein $(8 \%$ of the initial protein mass) compared to proteinrestricted sows (11 and $13.5 \%$ for 180LP and 240LP, respectively). Nevertheless, the greater mobilization of lean tissue in proteinrestricted sows is illustrated by increased circulating concentrations of glutamine and alanine. Alterations in pre-prandial profiles of circulating AA in protein-restricted sows indicate that protein mobilization does not compensate for a low dietary protein intake with respect to individual AA concentrations, at least in late lactation. Moreover, dif- ferences in pre-prandial concentrations of several AA between the 180LP and 240LP sows (e.g. lysine, valine, isoleucine, phenylalanine, tryptophan) indicate that the metabolic status of these sows differed. Plasma urea and $\alpha$-amino nitrogen are, respectively, final and intermediary products of protein metabolism. The ratio of urea to $\alpha$-amino nitrogen therefore reflects the efficiency of protein use. This efficiency was greater at the end of lactation in protein-restricted sows and proteins originating from the diet and maternal muscles were then greatly used for the synthesis of milk proteins. The urea to $\alpha$-amino-nitrogen ratio did not allow discrimination between the two groups of protein-restricted sows, despite the different losses in protein reserves in these sows.

Sows from all treatments lost the same proportion of fat mass. Yet, the 240LP sows 
lost twice the amount of lipids as sows from the other treatments while having similar profiles of NEFA around weaning. This could be partly explained by the fact that the difference in lipid loss between the treatment groups was attenuated during the fourth week of lactation compared with early lactation (data not shown). The lack of difference in NEFA concentrations between sows from different treatments may also be explained by a high mammary uptake of NEFA [35] as well as a high NEFA uptake for lipid turn-over in adipose tissue, in the 240LP sows.

Consistent with previous findings [8], protein (lysine) restriction throughout lactation induced an uncoupling between IGF-I and GH secretions in the 180LP sows. Such uncoupling was shown to result from hepatic resistance to $\mathrm{GH}$, which is related to low plasma insulin concentrations. Indeed, insulin release after the meal was lower in the 180LP sows. This uncoupling between $\mathrm{GH}$ and IGF-I secretions likely facilitates mobilization of lean tissue, because of the anabolic effects of IGF-I on AA deposition in muscle tissue. The reduction in plasma IGF-I concentrations around weaning (days $\mathrm{W}-1$ and $\mathrm{W}+1$ ) in the 180LP sows is in accordance with previous data $[8,36]$. In contrast, Clowes et al. [37, 38] reported no influence of low protein intake on plasma IGF-I concentrations throughout lactation. Reasons for such discrepancies are not known.

It is interesting to note that, in the present experiment, concentrations of IGF-I around weaning were similar in the $240 \mathrm{LP}$ and 180CP sows, despite the lower ingestion of protein (and of energy) by the 240LP sows. Large body reserves may have played a protective role against the detrimental effect of protein restriction on peripheral IGF-I concentrations. This was previously suggested by van den Brand et al. [39], who reported that body weight at farrowing interacts with body weight loss during lactation to affect IGF-I concentrations at weaning.
Weaning is known to be associated with dramatic changes in the metabolic and hormonal statuses of the sow and the present observations were consistent with such findings (for review see $[11,40]$ ). Indeed, lactation cessation by piglet removal was associated with a drop in concentrations of $\mathrm{GH}$ and prolactin, as previously reported [4143]. Preprandial concentrations of glucose and insulin increased after weaning and those of NEFA decreased, indicating a change towards a less catabolic state $[41,43]$. The low ratio of urea to $\alpha$-amino nitrogen in all sows suggests that dietary proteins were extensively used, likely to rebuild lean body reserves and achieve body growth. As previously described in sows that were feed- or protein-restricted during lactation $[8,10]$, IGF-I concentrations remained low on the day after weaning. The IGF-I response to change in the metabolic status at weaning was shown to take several days, indicating a delayed metabolic consequence of poor nutrient intake during lactation [39, 44]. As previously reported [8], leptin concentrations increased between day $\mathrm{W}-1$ and day $\mathrm{W}+1$ in protein-restricted sows, this increase being significant in heavy sows (240LP). Mean and post-prandial concentrations of leptin on days $\mathrm{W}-1$ and $\mathrm{W}+1$ were positively correlated to estimated body lipids at weaning $(P<0.001)$ and were negatively correlated to lipid loss during lactation $(P<$ 0.001). Nevertheless, the increase in leptin secretion between day $\mathrm{W}-1$ and day $\mathrm{W}+1$ occurred without notable changes in sows' body lipid contents. The physiological origin of this increase remains to be investigated but it illustrates another delayed postweaning consequence of protein (lysine) restriction during lactation, on sow metabolism.

In the present experiment, lysine intake in protein-restricted sows was greatly below the requirement for milk production (40$\left.45 \mathrm{~g} \cdot \mathrm{d}^{-1},[5,45]\right)$. The overall reduction of litter growth rate in protein-restricted sows is consistent with previous findings $[4,36$, 37]. Daily litter growth rate was negatively correlated with mean concentrations of 
alanine and glutamine, which are known as good indicators of lean tissue mobilization $(r=-0.44, P=0.002$ and $r=-0.40, P=0.005$, respectively). However, litter growth in the current experiment here was reduced as early as in the first week of lactation, whereas Clowes et al. [37, 38] observed a reduction only after d 20 of lactation, once sows had lost 9 to $12 \%$ of their calculated protein mass. Poor lactation performance in the present experiment was therefore not primarily related to the depletion of body protein reserves. Prolactin concentrations did not differ between sows at the end of lactation, while differences in litter growth were still marked. This rules out an involvement of prolactin in the poor milk production of proteinrestricted sows. As suggested by Clowes et al. [38], the AA mixture released from endogenous proteins may not perfectly match the AA required for milk protein synthesis. This hypothesis is supported by the reduction in milk proteins reported as early as on $\mathrm{d} 8$ or 10 of lactation in sows subjected to dietary protein restriction $[38,46]$.

We previously observed no significant effect of protein restriction on litter growth from primiparous sows weighing $210 \mathrm{~kg}$ at farrowing [8] and suggested that a large initial body protein mass may be adequate to sustain lactation. In the present experiment, it is likely that heavy sows (240LP) could not cope because of their reduced appetite, which led to a more negative energy and lysine balance. Increasing lean tissue reserves at farrowing without increasing fat reserves could be more efficient than increasing fat reserves to buffer the negative impact of low protein intake during lactation on sow body reserves and milk production.

In conclusion, numerous characteristics of the sow metabolic profiles at the end of lactation are modified by dietary protein restriction, and increasing both fat and protein stores at farrowing does not allow complete restoration of these profiles (e.g. AA profiles). Similarly, large body reserves at farrowing may not be sufficient to prevent poor milk production or milk quality, which seemed more likely related to insufficient or inadequate AA availability than to depletion of body protein reserves.

\section{ACKNOWLEDGEMENTS}

The authors wish to acknowledge C. Homo, B. Duteil, M. Massard for taking care of the animals, Y. Lebreton for performing surgery, Y. Colléaux, M. Lefebvre and C. David for technical assistance. The authors also thank Dr Louveau (INRA Saint-Gilles, France) and Dr Weiler (University of Hohenheim, Germany) for providing antiserum against IGF-I and NHPP, NIDDK and Dr A.F. Parlow (Torrance, Ca) for providing pGH-Bio. C. Mejia-Guadarrama was supported by a scholarship from CONACYT/ INIFAP (México) and SFERE (France).

\section{REFERENCES}

[1] O'Grady JF, Lynch PB, Kearney PA. Voluntary feed intake by lactating sows. Livest Prod Sci 1985, 12: 355-365.

[2] Noblet J, Dourmad J-Y, Etienne M. Energy utilization in pregnant and lactating sows: modeling of energy requirements. J Anim Sci 1990, 68: 562-572.

[3] King RH, Williams IH. The effect of nutrition on the reproductive performance of first-litter sows. 2. Protein and energy intakes during lactation. Anim Prod 1984, 38: 249-256.

[4] Jones DB, Stahly TS. Impact of amino acid nutrition during lactation on body nutrient mobilization and milk nutrient output in primiparous sows. J Anim Sci 1999, 77: 15131522.

[5] Dourmad J-Y, Noblet J, Etienne M. Effect of protein and lysine supply on performance, nitrogen balance, and body composition changes of sows during lactation. J Anim Sci 1998, 76: 542-550.

[6] King RH, Dunkin AC. The effect of nutrition on the reproductive performance of first-litter sows. 4. The relative effects of energy and protein intakes during lactation on the reproductive performance of sows and their piglets. Anim Prod 1986, 43: 319-325.

[7] Brendemuhl JH, Lewis AJ, Peo ER Jr. Effect of protein and energy intake by primiparous sows during lactation on sow and litter performance and sow serum thyroxine and urea 
concentrations. J Anim Sci 1987, 64: 10601069.

[8] Mejia-Guadarrama C.A., Pasquier A, Dourmad J-Y, Prunier A, Quesnel H. Protein (lysine) restriction in primiparous lactating sows: Effects on metabolic state, somatotropic axis, and reproductive performance after weaning. J Anim Sci 2002, 80: 3286-3300.

[9] Etienne M, Legault C, Dourmad J-Y, Noblet J. Production laitière de la truie : estimation, composition, facteurs de variation et évolution [Milk production in the sow: estimation, composition, factors of variation and evolution]. J Rech Porcine France 2000, 32: 253264.

[10] Zak LJ, Cosgrove JR, Aherne FX, Foxcroft GR. Pattern of feed intake and associated metabolic and endocrine changes differentially affect postweaning fertility in primiparous lactating sows. J Anim Sci 1997, 75: 208-216.

[11] Quesnel H, Prunier A. Endocrine bases of lactational anoestrus in the sow. Reprod Nutr Dev 1995, 35: 395-414.

[12] NRC. In: Nutrient Requirements of Swine. 9th ed. Natl Acad Press, Washington DC, 1988, p 49-53.

[13] INRA. L'alimentation des animaux monogastriques. 2nd ed. Institut National de la Recherche Agronomique, Paris, France, 1989.

[14] Quesnel H, Mejia-Guadarrama C.A., Pasquier A, Dourmad J-Y, Prunier A, Dietary protein restriction during lactation in primiparous sows with different live weight at farrowing: II. Consequences on reproductive performance and interactions with metabolic status. Reprod Nutr Dev 2005, 45: 57-68.

[15] Camous S, Prunier A, Pelletier J. Plasma prolactin, LH, FSH and estrogen excretion patterns in gilts during sexual development. J Anim Sci 1985, 60: 1308-1317.

[16] Chacornac JP, Barnouin J, Houlier ML. Microdosage automatisé sur analyseur à transfert de 1'azote $\alpha$-aminé circulant. Reprod Nutr Dev 1993, 33: 99-108.

[17] Sève B, Meunier-Salaün MC, Monnier M, Colléaux Y, Henry Y. Impact of dietary tryptophan and behavioral type on growth performance and plasma amino acids of young pigs. J Anim Sci 1991, 69: 3679-3688.

[18] Prunier A, Martin C, Mounier AM, Bonneau M. Metabolic and endocrine changes associated with undernutrition in the peripubertal gilt. J Anim Sci 1993, 71: 1887-1894.

[19] Louveau I, Bonneau M, Salter DN. Agerelated changes in plasma porcine growth hormone $(\mathrm{GH})$ profiles and insulin-like growth
factor-I (IGF-I) concentrations in Large White and Meishan pigs. Reprod Nutr Dev 1991, 31: 205-216.

[20] Louveau I, Bonneau M. Effect of a growth hormone infusion on plasma insulin-like growth factor-I in Meishan and Large White pigs. Reprod Nutr Dev 1996, 36: 301-310.

[21] Robert S, de Passillé AMB, St-Pierre N, Dubreuil P, Pelletier G, Petitclerc D, Brazeau P. Effect of the stress of injections on the serum concentration of cortisol, prolactin and growth hormone in gilts and lactating sows. Can J Anim Sci 1989, 69: 663-672.

[22] Qian H, Barb CR, Compton MM, Hausman GJ, Azain MJ, Kraeling RR, Baile CA. Leptin mRNA expression and serum leptin concentrations as influenced by age, weight, and estradiol in pigs. Domest Anim Endocrinol 1999, 16: 135-143.

[23] Whisnant CS, Harrell RJ. Effects of shortterm feed restriction and refeeding on serum concentrations of leptin, luteinizing hormone and insulin in ovariectomized gilts. Domest Anim Endocrinol 2002, 22: 73-80.

[24] Dourmad J-Y, Etienne M, Noblet J. Prédiction de la composition chimique des truies reproductrices à partir du poids vif et de l'épaisseur de lard dorsal. Application à la définition des besoins énergétiques. J Rech Porcine France 1997, 29: 255-262.

[25] Littell RC, Milliken GA, Stroup WW, Wolfinger RD. SAS system for Mixed Models, SAS Institute Inc., Cary, NC, 1996.

[26] Dourmad JY. Effect of feeding level in the gilt during pregnancy on voluntary feed intake during lactation and changes in body composition during gestation and lactation. Livest Prod Sci 1991, 27: 309-319.

[27] Weldon WC, Lewis AJ, Louis GF, Kovar JL, Giesemann MA, Miller PS. Postpartum hypophagia in primiparous sows. I. Effects of gestation feeding level on feed intake, feeding behaviour, and plasma metabolite concentrations during lactation. J Anim Sci 1994, 72: 387-394.

[28] Dourmad JY. Ingestion spontanée d'aliment chez la truie en lactation: de nombreux facteurs de variation. INRA Prod Anim 1988, 1: 141-146.

[29] Weldon WC, Lewid AJ, Louis GF, Kovar JL, Miller PS. Postpartum hypophagia in primiparous sows. II. Effects of feeding level during gestation and exogenous insulin on lactation feed intake, glucose tolerance, and epinephrine-stimulated release of nonesterified fatty acids and glucose. J Anim Sci 1994, 72: 395-403. 
[30] Xue JL, Koketsu Y, Dial GD, Pettigrew JE, Sower A. Glucose tolerance, luteinizing hormone release, and reproductive performance of first-litter sows fed two levels of energy during gestation. J Anim Sci 1997, 75: 18451852 .

[31] Le Cozler Y, David C, Beaumal, V., Johansen S, Dourmad JY. Effect of the feeding level during rearing on performance of Large White gilts. Part 2. Effect on metabolite profiles during gestation and lactation, and on glucose tolerance. Reprod Nutr Dev 1998, 38: 377-390.

[32] Barb CR, Yan X, Azain MJ, Kraeling RR, Rampacek GB, Ramsay TG. Recombinant porcine leptin reduces feed intake and stimulates growth hormone secretion in swine. Domest Anim Endocrinol 1998, 15: 77-86.

[33] Prunier A, Mejia Guadarrama C., Mourot J, Quesnel H. Influence of feed intake during pregnancy and lactation on fat body reserve mobilisation, plasma leptin and reproductive function of primiparous lactating sows. Reprod Nutr Dev 2001, 41: 333-347.

[34] Estienne MJ, Harper AF, Kozink DM, Knight JW. Serum and milk concentrations of leptin in gilts fed a high- or low-energy diet during gestation. Anim Reprod Sci 2003, 75: 95-105.

[35] Dourmad J-Y, Matte JJ, Renaudeau D. Effect of the meal on the utilization of some nutrients and vitamins by the mammary gland in lactating sows. J Anim Sci 2002, 80 (Suppl 1): 193 (abstract).

[36] Yang H, Pettigrew JE, Johnston LJ, Shurson GC, Wheaton JE, White ME, Koketsu Y, Sower AF, Rathmacher JA. Effects of dietary lysine intake during lactation on blood metabolites, hormones, and reproductive performance in primiparous sows. J Anim Sci 2000, 78: 1001-1009.

[37] Clowes EJ, Aherne FX, Foxcroft GR, Baracos VE. Selective protein loss in lactating sows is associated with reduced litter growth and ovarian function. J Anim Sci 2003, 81: 753764.
[38] Clowes EJ, Aherne FX, Schaefer AL, Foxcroft GR, Baracos VE. Parturition body size and body protein loss during lactation influence performance during lactation and ovarian function at weaning in first-parity sows. J Anim Sci 2003, 81: 1517-1528.

[39] Van Den Brand H, Prunier A, Soede NM, Kemp B. In primiparous sows, plasma insulinlike growth factor-I can be affected by lactational feed intake and dietary energy source and is associated with luteinizing hormone. Reprod Nutr Dev 2001, 41: 27-39.

[40] Varley MA, Foxcroft GR. Endocrinology of the lactating and weaned sow. J Reprod Fertil Suppl 1990, 40: 47-61.

[41] Armstrong JD, Britt JH, Kraeling RR. Effect of restriction of energy during lactation on body condition, energy metabolism, endocrine changes and reproductive performance in primiparous sows. J Anim Sci 1986, 63: 1915-1925.

[42] Schams D, Kratzl WD, Brem G, Graf F. Secretory pattern of metabolic hormones in the lactating sow. Exp Clin Endocrinol 1994, 102: 439-447.

[43] Quesnel H, Pasquier A, Mounier AM, Louveau I, Prunier A. Influence of feed restriction in primiparous lactating sows on body condition and metabolic parameters. Reprod Nutr Dev 1998, 38: 289-303.

[44] Quesnel H, Prunier A. Endocrine mechanisms mediating nutritional effects on fertility in the gilt and sow. In: Proc First Congress of the Latin American Annual Nutrition College, August 18-23, 2003, Cancun, Mexico.

[45] King RH, Toner MS, Dove H, Atwood CS, Brown WG. The response of first-litter sows to dietary protein level during lactation. J Anim Sci 1993, 71: 2457-2463.

[46] Kusina J, Pettigrew JE, Sower AF, White ME, Crooker BA, Hathaway MR. Effect of protein intake during gestation and lactation on the lactational performance of primiparous sows. J Anim Sci 1999, 77: 931-941. 